УДК 629.1.02

DOI: https://doi.org/10.26642/ten-2019-2(84)-21-28

\author{
А.П. Кожушко, к.т.н., доц. \\ Національний технічний університет \\ «Харківський політехнічний інститут» \\ І.В. Колсснік, к.т.н., асистент \\ В.В. Лупенко, магістрант \\ Харківський національний технічний університет \\ сільського господарства імені Петра Василенка
}

\title{
Методика експериментального дослідження визначення динамічних характеристик при русі колісних тракторів 3 агрегатами змінної маси
}

Сьогодні актуальним та невирішеним питанням є дослідження транспортних робіт, які використовуються в аграрному секторі, адже виникає проблема при дослідженні руху машиннотракторного агрегату з причіпними або напівпричіпними агрегатами. Це пов'язано безпосередньо з нарощуванням енергонасиченості колісних тракторів $i$, як наслідок, намаганням максимально підвищити продуктивність транспортного засобу. Великий інтерес викликає дослідження транспортної роботи при перевезенні рідкого вантажу, де підвищення вантажоперевезень призводить до виникнення суттєвого впливу при експлуатації колісного трактора та тракторної цистерни (яка позбавлена внутрішніх перегородок) за рахунок власних коливань рідини. Цей процес призводить до поздовжньої та поперечної нестабільності, що сприяє підвищенню як динамічних характеристик, так і аварійних ситуачій (відбувається вплив на плавність руху, вібронавантаженість, керованість та стійкість транспортного засобу, підвищення динамічної навантаженості ходової системи тощо). Тому задля підтвердження теоретичних викладок впливу коливань рідини в тракторній ияистерні необхідно проводити експериментальні дослідження. Наведена в иій статті методика експериментального дослідження дозволить визначити динамічні характеристики при транспортуванні причіпних та напівпричіпних тракторних цистерн за сталого руху $i$ на перехідних режимах роботи. Практична значущість роботи полягає в отриманні експериментальних даних прискорень досліджуваних об'єктів при різновисотній наповненості цистерн.

Ключові слова: колісний трактор; иистерна; динаміка; прискорення; експериментальні дослідження; вимірювальний комплекс.

Актуальність теми. Згідно 3 стратегією розвитку аграрного сектору України передбачено підвищення врожайності, що передбачає зростання як тягових (технологічних), так і транспортних робіт. Транспортна робота, зазвичай, виконується вантажними автомобілями або колісними тракторами разом 3 причіпними та напівпричіпними агрегатами.

Сьогодні актуальною проблемою в сільському господарстві $є$ вирішення забезпечення стійкого руху транспортних засобів зі змінною масою (перевезення рідких вантажів). Особливої уваги слід надати транспортуванню тракторних причіпних та напівпричіпних цистерн, тому що на відмінну від автомобільних, тракторні не оснащені перегородками (це передбачено відносно малою швидкістю перевезень, порівняно з автомобілем), які мають гасити коливання рідини в цистерні. Оскільки сучасні виробники тракторної техніки намагаються постійно підвищувати енергонасиченість колісних тракторів та збільшувати масу транспортованого вантажу [1], тоді перерозподіл мас в цистерні може спричинити погіршення техніко-економічних та експлуатаційних показників колісного трактора.

Аналіз останніх досліджень та публікації, на які спирається автор. У багатьох науковометричних джерелах [2-8] динаміка руху оцінюється за показниками лінійних прискорень, що діють на дослідний об’єкт. Саме цей показник може як надати повний аналіз системи, так і характеризувати вплив одного об'єкта на інший (наприклад, вплив на рух колісного трактора при агрегатуванні цистерною). Окрім того, за допомогою оцінки лінійних прискорень можна дослідити зміну техніко-економічних та експлуатаційних (стійкість, маневреність тощо) показників і ін. Проте в науковій літературі жодним чином не окреслено кількісного впливу на динамічні показники при виконанні транспортної роботи колісним трактором з агрегатом перемінної маси (зокрема, цистерною).

Метою статті є наведення методики експериментального дослідження визначення динамічних характеристик транспортного засобу (колісного трактора) в зчіпці з агрегатами змінної маси (причіпної (П) та/або напівпричіпної (НП) цистернами) при виконанні транспортної роботи.

Для досягнення поставленої мети необхідно оцінити умови проведення випробувань, навести об'єкти експериментальних досліджень, завдання випробувань, прилади та апаратуру. 
Викладення основного матеріалу. Умови проведення експериментальних досліджень відповідали умовам роботи колісних тракторів загального призначення при виконанні транспортних робіт. Експериментальні дослідження проводилися в одному з фермерських угідь Харківської області. Де як полігон обиралася ділянка укоченої грунтової дороги, яка мала довжину 200 м, а їі нахил складав не більше $2 \%$.

Порядок проведення експериментальних досліджень:

1. Зовнішнім оглядом перевіряється технічний стан колісних машин.

2. На колісний трактор встановлюється вимірювальна апаратура.

3. Встановлена вимірювальна апаратура проходить процес калібрування та перевіряється іiі працездатність після фіксування затискачами на елементи агрегатів трактора.

4. Виконуються пробні заїзди, які надають інформацію щодо необхідності додаткового калібрування вимірювальної апаратури.

5. На перехідних режимах руху (розгоні та гальмуванні) та на сталому режимі руху відбувається фіксація експериментальних даних.

6. До колісного трактора чіпляється П-цистерна та на неї встановлюється вимірювальна апаратура.

7. Повторюється пункт 4. Заїзди виконуються з порожньою цистерною.

8. МТА разом з цистерною (яка заповнюється рідиною до рівня 1,7 м для П-цистерни) транспортується до місця проведення експериментів.

9. Після фіксації результатів 3 повністю заповненою цистерною проводиться злив $15 \%$ рідини (тобто для П-цистерни до 1,45 м). Після чого повторюється операція 5.

10. Наступним кроком також проводиться злив $20 \%$ рідини (для П-цистерни до 1,15 м). Після чого повторюється операція 5.

11. На завершальній стадії випробувань проводиться тестовий заїзд 3 порожньою цистерною для виконання порівняння результатів $з$ операцією № 7, що дасть змогу стверджувати про похибку приладів.

Потім наведений порядок повторюється, тільки замість П-цистерни в зчіпці з трактором виступає НП-цистерна, яка має максимальну висоту заповнення рідиною 1,4 м.

Зауважимо, що експериментальні заїзди для пунктів випробувань № 6, 7 та 8 проводилися не менше трьох разів згідно з ГОСТ 7057-2003 [10], 24055-2016 [11], СОУ-ІІ УкрНДІПВТ ім. Л.Погорілого 71.2-37046043090-017:2015 [12].

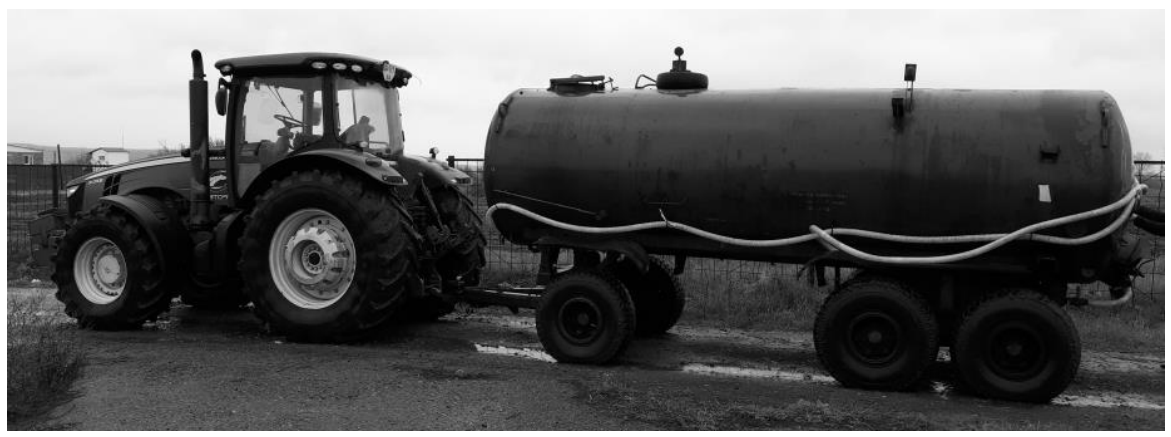

a)

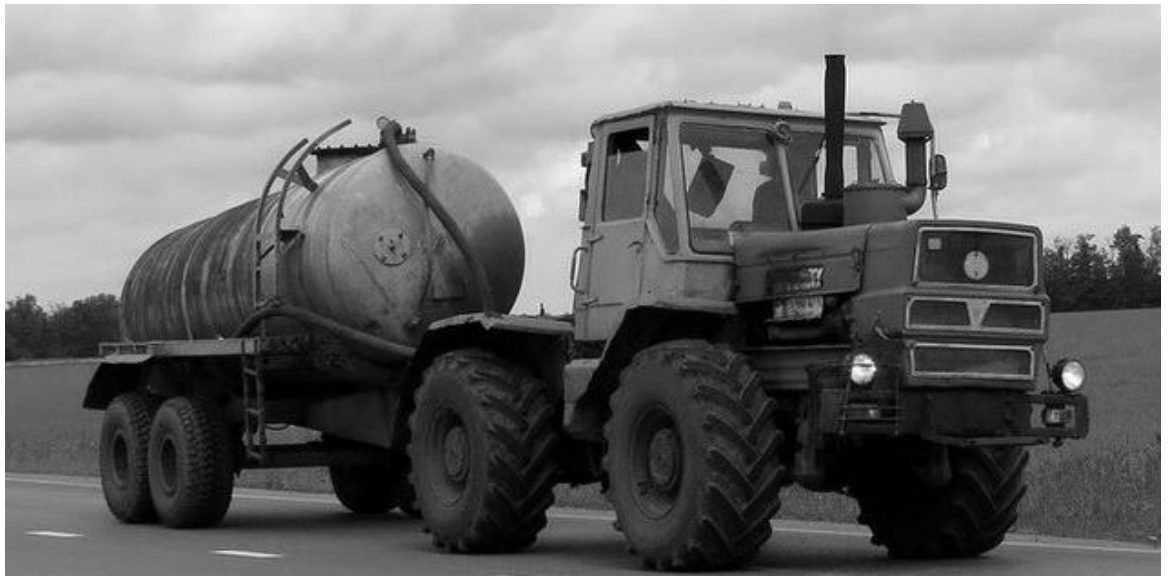

б)

Рис. 1. Об'єкти експериментальних досліджень: a) - John Deere + MЖT-16; б) - XT3-150K + MЖT-10 
Об'єктом випробувань $є$ (рис. 1):

- трактор John Deere 8310 (США) з номінальною потужністю двигуна внутрішнього згоряння 310 к.c. (228 кВт) в зчіпці з П-цистерною МЖТ-16 (Білорусь) вантажопідйомністю 16 т;

- трактор ХТЗ-150К (Україна) з номінальною потужністю двигуна внутрішнього згоряння 129 к.с. (94,9 кВт) в зчіпці з НП-цистерною МЖТ-10 (Білорусь) вантажопідйомністю 10 т.

На рисунку 2 наведено схему розташування вимірювальних приладів на колісному тракторі та цистерні. Вимірювальні прилади, що застосовуються, такі: мобільний вимірювальний комплекс (який складається з 4-х акселерометрів) та безконтактного датчика (радіолокаційний).

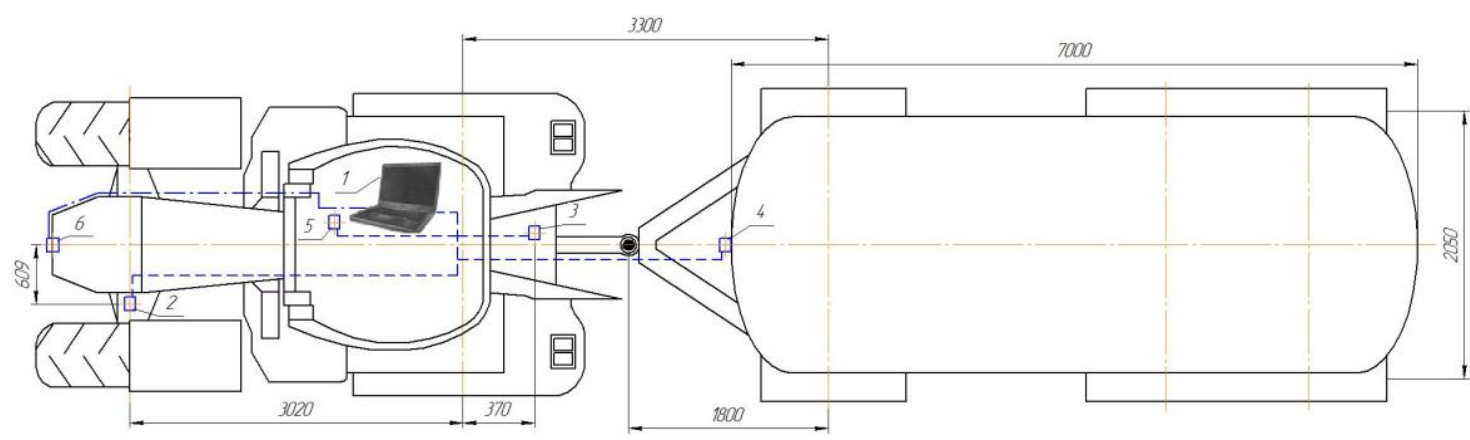

a)

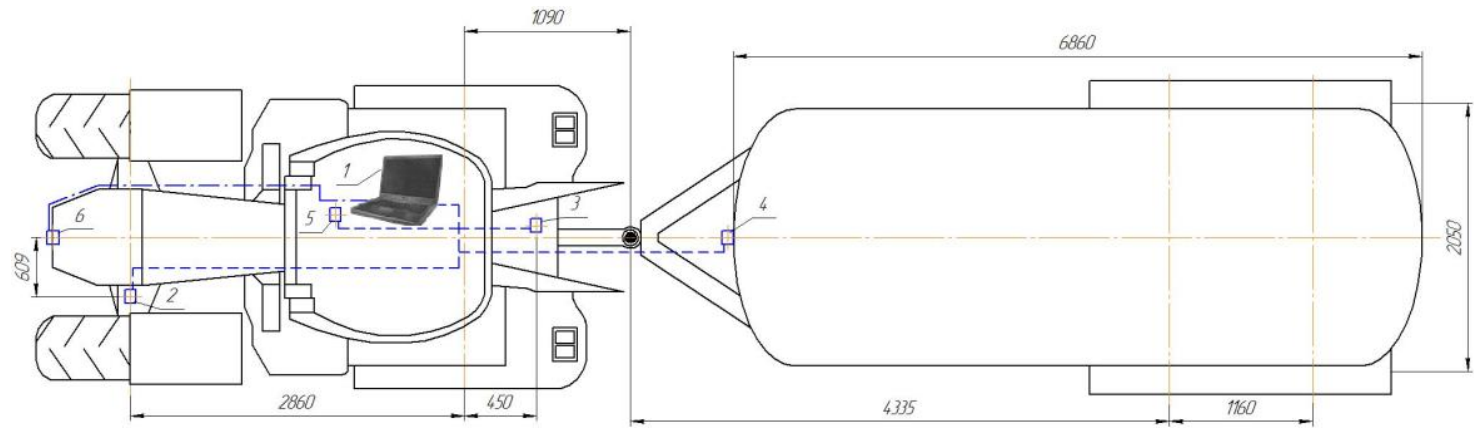

б)

Рис. 2. Схема розташування вимірювальних приладів:

а) - П-циистерна; б) - НП-цистерна,

1 -ноутбук; 2, 3, 4, 5-акселерометри;

6 - безконтактний датчик (радіолокаційний)

Мобільний вимірювальний комплекс «ВДВММ 4-001» Паспорт 4-001.000.00 ПС [9], представлений на рисунку 3, складається 3 4-х акселерометрів Freescale Semiconductor моделі MMA7260QT. Акселерометри складаються 3 двох конструкцій ємнісного типу (G-осередків) та системи ASIC (який формує сигнал), які об'єднані однією інтегральною мікросхемою. Чутливі елементи акселерометра надійно і герметично закриті завдяки об'ємній цокольній пластині. G-осередок має механічну структуру, який сформовано 3 напівпровідникових матеріалів та використовує напівпровідникові процеси. Конструкція представляє собою сукупністю нерухомих вантажів, що кріпляться до рухомої центральної маси, яка, в свою чергу, переміщується. Рухомі маси відхиляються від рівноважного стану, тим самим змушуючи систему прискорюватися. Система ASIC використовує методи комутації конденсаторів для вимірювання їх ємностей та вилучення даних прискорення.

Акселерометри, що використовуються, мають змогу фіксувати лінійне прискорення в трьох площинах (горизонтальній, вертикальній і боковій) з чутливістю $1,5 g, 2 g, 4 g, 6 g$ та мають максимальну похибку в $1 \%$. Використання акселерометрів Freescale Semiconductor моделі MMA7260QT досить популярне, що обумовлено встановленням чисельних значень в трьох площинах прискорень транспортного засобу з агрегатами перемінної маси, що дасть змогу оцінити динамічні якості. 


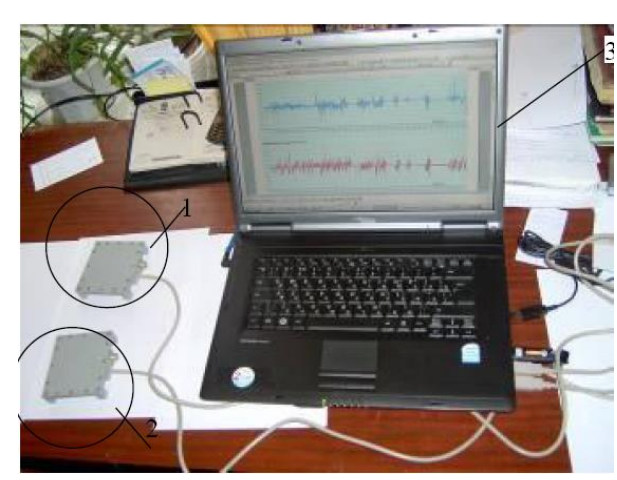

a)

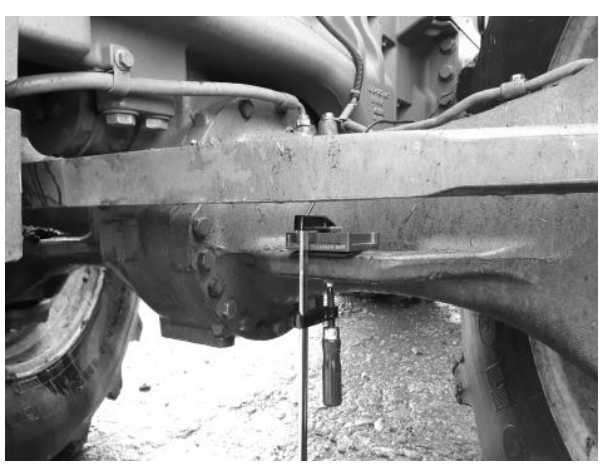

б)

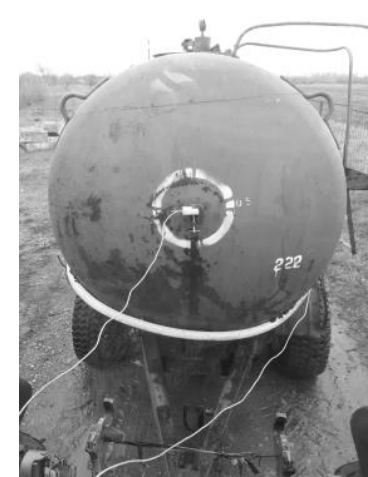

в)

Рис. 3. Мобільний вимірювальний комплекс «ВДВММ 4-001»:

1, 2 - акселерометри; 3 - ноутбук; а) - загальний вид;

б) - в) - розмішення датчиків на John Deere + МЖТ-16:

б) - на передньому мосту; в) - спереду П-циистерни

Безконтактний датчик (радіолокаційний) являє собою конструкцію (рис. 4), яка складається з радару, антени та кріпильного механізму. Принцип роботи цього датчика описано в роботах [7], а саме, віддзеркалений сигнал являє собою складний частотний сигнал, спектр якого зміщується в частотночасовій ділянці. Отож, встановлення реальної поточної швидкості транспортного засобу відбувається за рахунок обчислення енергетичного 3D спектра [7].

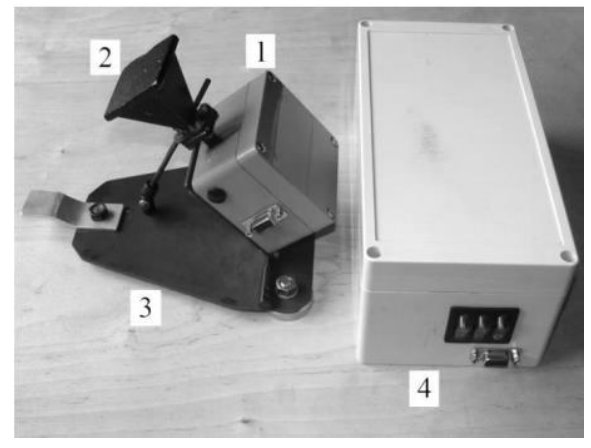

a)

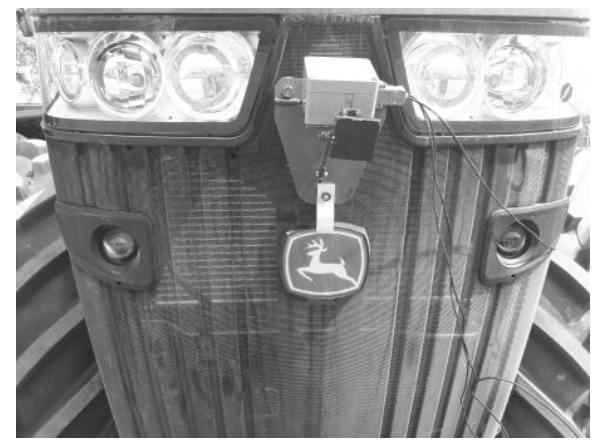

б)

Рис. 4. Радіолокаиійний безконтактний датчик:

а) - загальний вид; б) - встановлено на трактор John Deere;

1 -радар; 2 -антена; 3 -магнітна платформа; 4 -інтерфейс та блок живлення

Результати експериментального дослідження розміщені в таблиці 1, в якій представлено алгоритм проведення випробувань для John Deere в зчіпці з МЖТ-16. Для трактора ХТЗ-150К з МЖТ-10 цей алгоритм повторюється з врахуванням заявленої швидкості руху (1 м/с та 4,4 м/c).

Фільтрація сигналу з будь-якого акселерометра передбачає обробку багатого на перешкоди сигналу. Розуміння обробки полягає в пропусканні сигналу певних частот, затримувати або зменшувати сигнали, які підпорядковані іншим частотам $[8,9]$. Основною характеристикою, якою необхідно користуватися при виборі певного фільтра, є його АЧХ. За їі видом розрізняють: фільтри нижніх частот, верхніх частот, смугово-пропускні чи смугові, смугово-затримуючі.

При обробці отриманих можуть застосовуватися фільтри нижніх частот, які розрізняються:

- фільтр Баттерворта з максимально плоскою амплітудно-частотною характеристикою;

- фільтр Чебишева (І роду) з рівноволновою характеристикою в смузі пропускання;

- інверсний фільтр Чебишева (II роду) з рівноволновою характеристикою в смузі затримування;

- еліптичний фільтр, що має рівноволнові характеристики в смузі пропускання та смузі затримування;

- фільтр Бесселя з фазочастотною характеристикою, близькою до лінійної. 
Результати досліджень руху колісного трактора з агрегатами змінної маси

\begin{tabular}{|c|c|c|c|c|c|c|c|}
\hline Трактор & Вид руху & $\begin{array}{c}\text { Обрана передача } \\
\text { (заявлена } \\
\text { швидкість, м/с) }\end{array}$ & $\begin{array}{c}\text { Рівень } \\
\text { заповнення } \\
\text { рідини } H, \\
\text { м }\end{array}$ & $\begin{array}{c}\mathbf{V}, \\
\text { км/год }\end{array}$ & $\begin{array}{c}a_{x} \\
\mathbf{M} / \mathbf{c}^{2}\end{array}$ & $\begin{array}{c}a_{y} \\
\mathbf{M} / \mathbf{c}^{2}\end{array}$ & $\begin{array}{c}a_{z} \\
\mathbf{M} / \mathbf{c}^{2}\end{array}$ \\
\hline \multirow{6}{*}{ 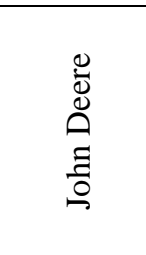 } & \multirow{2}{*}{ Розгін } & 3 передача (1 м/c) & \multirow{6}{*}{-} & & & & \\
\hline & & 13 передача $(4,4$ м/c) & & & & & \\
\hline & \multirow{2}{*}{ Сталий рух } & 3 передача $(1 \mathrm{~m} / \mathrm{c})$ & & & & & \\
\hline & & 13 передача $(4,4$ м/c) & & & & & \\
\hline & \multirow{2}{*}{ Гальмування } & 3 передача $(1 \mathrm{~m} / \mathrm{c})$ & & & & & \\
\hline & & 13 передача $(4,4$ м/c) & & & & & \\
\hline \multirow{18}{*}{ 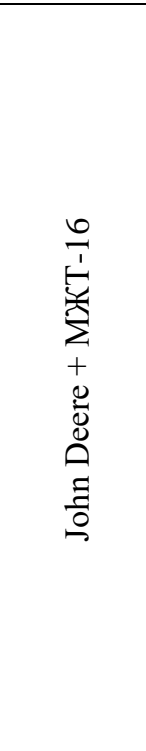 } & \multirow{2}{*}{ Розгін } & 3 передача $(1$ м/c) & \multirow{6}{*}{1,7} & & & & \\
\hline & & 13 передача $(4,4$ м/c) & & & & & \\
\hline & \multirow{2}{*}{ Сталий рух } & 3 передача (1 м/c) & & & & & \\
\hline & & 13 передача (4,4 м/c) & & & & & \\
\hline & \multirow{2}{*}{ Гальмування } & 3 передача (1 м/c) & & & & & \\
\hline & & 13 передача (4,4 м/c) & & & & & \\
\hline & \multirow{2}{*}{ Розгін } & 3 передача $(1$ м/c) & \multirow{6}{*}{1,45} & & & & \\
\hline & & 13 передача $(4,4$ м/c) & & & & & \\
\hline & \multirow{2}{*}{ Сталий рух } & 3 передача (1 м/c) & & & & & \\
\hline & & 13 передача $(4,4$ м/c) & & & & & \\
\hline & \multirow{2}{*}{ Гальмування } & 3 передача $(1$ м/c) & & & & & \\
\hline & & 13 передача $(4,4$ м/c) & & & & & \\
\hline & \multirow{2}{*}{ Розгін } & 3 передача $(1 \mathrm{~m} / \mathrm{c})$ & \multirow{6}{*}{1,15} & & & & \\
\hline & & 13 передача $(4,4$ м/c) & & & & & \\
\hline & \multirow{2}{*}{ Сталий рух } & 3 передача $(1 \mathrm{~m} / \mathrm{c})$ & & & & & \\
\hline & & 13 передача $(4,4$ м/c) & & & & & \\
\hline & \multirow{2}{*}{ Гальмування } & 3 передача $(1 \mathrm{~m} / \mathrm{c})$ & & & & & \\
\hline & & 13 передача $(4,4$ м/c) & & & & & \\
\hline
\end{tabular}

Процес обробки експериментальних даних отриманих від акселерометрів, рекомендовано використовувати фільтр Баттерворта. Адже він має максимально пологу АЧХ на частотах смуги пропускання, яка рухається на частотах заглушування до біля нульового значення.

Аналоговий фільтр у загальному виді представляє лінійний селективно-частотний ланцюг, зміна якого визначається відношенням зображень Лапласа (передаточною функцією) вихідного $U_{2}(p)$ i вхідного $U_{1}(p)$ сигналів:

$$
H(p)=\frac{U_{2}(p)}{U_{1}(p)},
$$

де $p$ - комплексна частотна змінна, $p=j \omega$.

Оскільки передаточна функція лінійного ланцюга є дрібно-раціональною, то доцільно представити функцію, як відношення двох поліномів

$$
H(j \omega)=\frac{N(j \omega)}{D(j \omega)}=\frac{b_{m}(j \omega)^{m}+b_{m-1}(j \omega)^{m-1}+\ldots+b_{1}(j \omega)+b_{0}}{a_{n}(j \omega)^{n}+a_{n-1}(j \omega)^{n-1}+\ldots+a_{1}(j \omega)+a_{0}}, m \leq n .
$$

Конкретно для фільтра Баттерворта передаточна функція $n$-го порядку

$$
|H(j \omega)|^{2}=\frac{G_{0}^{2}}{1+\left(\frac{\omega}{\omega_{c}}\right)^{2 n}},
$$

де $G_{0}^{2}$ - квадрат коефіцієнта посилення за постійною складовою (на нульовій частоті);

$\omega_{c}$ - частота зрізу.

На рисунку 5 представлено АЧХ фільтра Баттерворта 1, 6 та 12 порядків. 


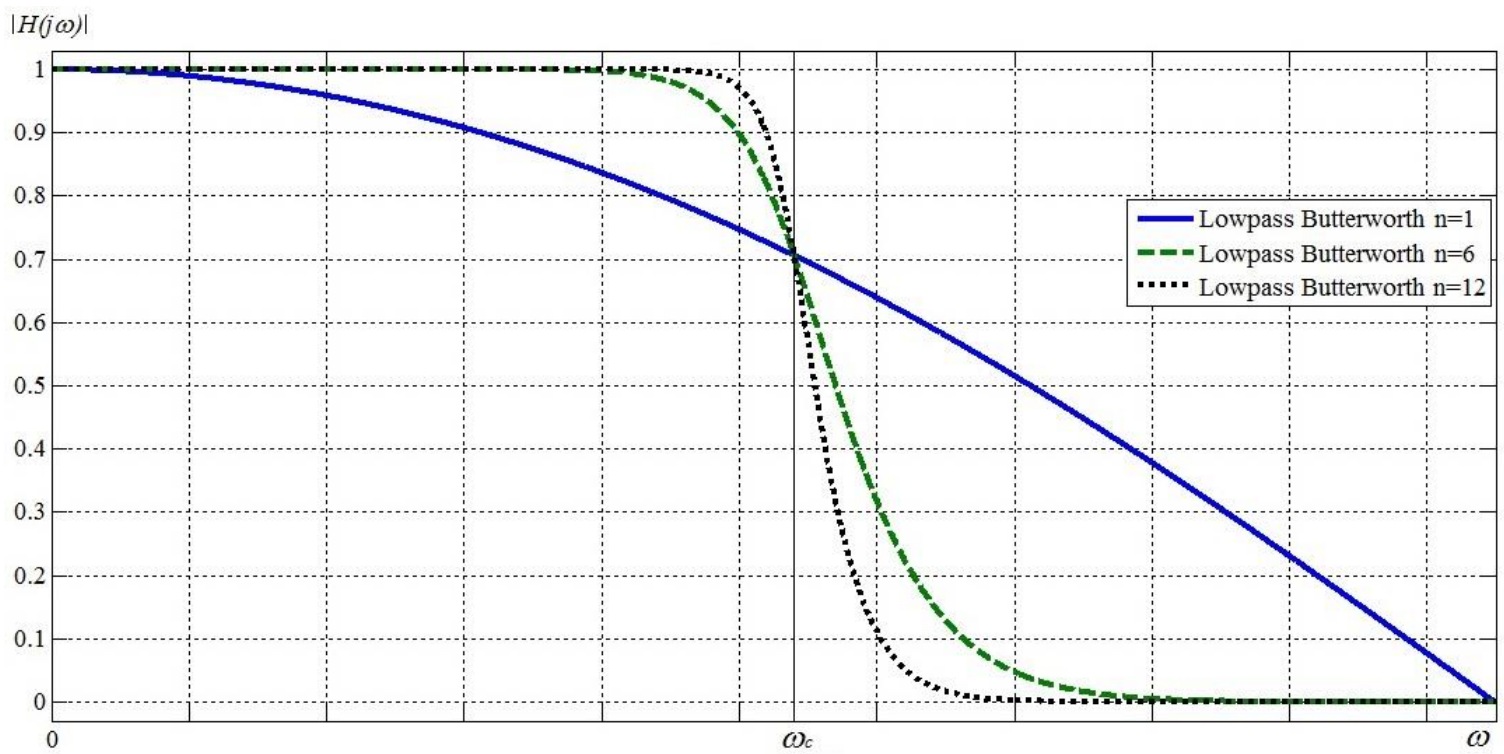

Рис. 5. АЧХ фільтра Баттерворта

3 рисунка 5 АЧХ фільтра Баттерворта при частоті зрізу дорівнює 0,7. 3 аналізу робіт [4] рекомендовано використовувати фільтр Баттерворта 12-го порядку з частотою заглушування 6 Гц. Такі характеристики фільтра мають підвищити точність оцінки експериментальних даних властивостей МТА при використанні акселерометрів. На рисунку 6 наведено результати використання фільтра Баттерворта на масив даних лінійних горизонтальних та вертикальних прискорень.

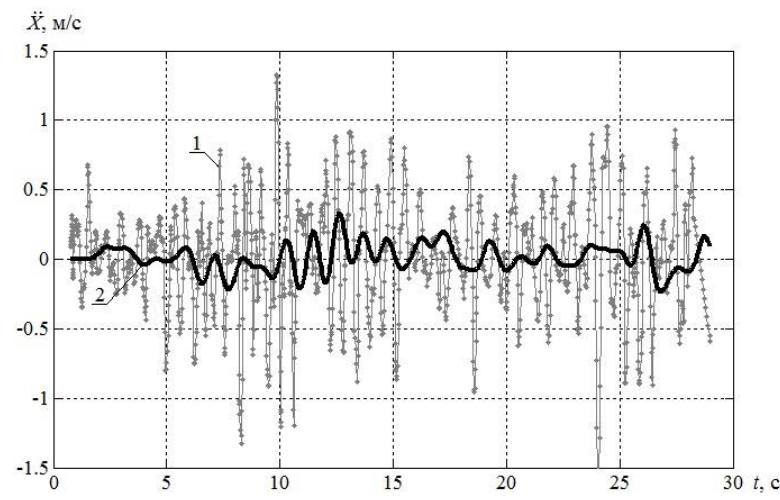

a)

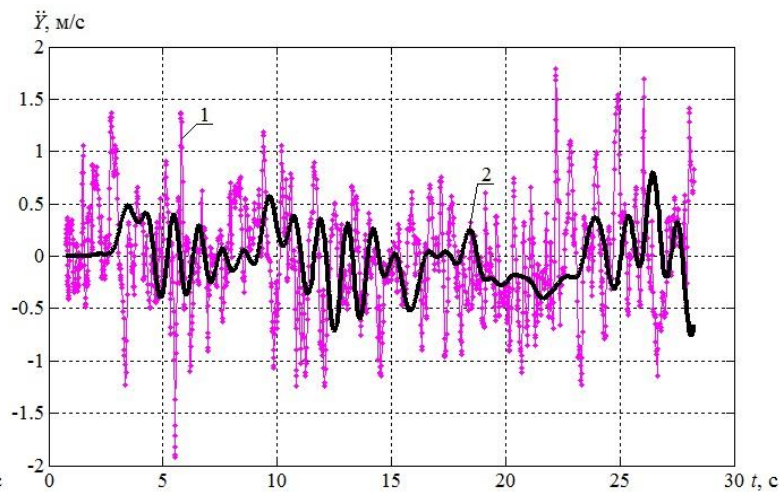

б)

Рис. 6. Відрізок лінійних прискорень трактора з агрегатом змінної маси: а) - горизонтальні; б) - вертикальні;

1 - вибірка прискорень; 2 - прискорення після використання фільтра Баттерворта

Таким чином, аналізуючи рисунок 6, можна з упевненістю стверджувати, що використання фільтра Баттерворта з рекомендаціями [4] дає змогу досягти значного згладжування (зменшення амплітуд шумового сигналу) вихідного сигналу з акселерометрів.

Перспективи подальших досліджень. Перш ніж виконувати важкі дослідні задачі з отриманими експериментальними даними необхідно мати уявлення щодо їх чисельних характеристик. Тому необхідно провести статистичний аналіз, який дозволить визначить закони розподілу та визначить діапазон зміни лінійних прискорень з заданою ймовірністю.

Висновки. Представлено методику експериментального дослідження, яка має надати вичерпну інформацію щодо зміни динамічних характеристик транспортного засобу (колісного трактора) в зчіпці 3 агрегатами змінної маси (причіпної та/або напівпричіпної цистерни) при виконанні транспортної роботи. Така методика має підтвердити теоретичні викладки (вплив різного рівня рідини в цистернах на динаміку руху транспортного засобу), які представлені в роботі [13]. 
Список використаної літератури:

1. Кожушко А.П. Аналіз конструктивних особливостей причіпних та напівпричіпних цистерн у складі машинно-тракторного агрегату / А.П. Кожушко // Вісник Національного технічного університету «ХПІ». Харків : НТУ «ХПІ», 2019. - № 5 (1330). - С. 34-40. - doi:10.20998/2413-4295.2019.05.05.

2. Langer T.H. Experimental analysis of occupational whole-body vibration exposure of agricultural tractor with large square baler / T.H. Langer, M.K. Ebbesen, A.Kordestani // International Journal of Industrial Ergonomics. - 2015. № 47. - P. 79-83. - doi: 10/1016/j.ergon.2015.02.009.

3. Analysis of vibration effects on the comfort of intercity bus users by oscillatory model with ten degrees of freedom / D.Sekulić, V.Dedović, S.Rusov and other // Applied Mathematical Modelling. - 2013. - T. 37. - № 18 19. - P. 8629-8644. - doi: 10.1016/j.apm.2013.03.060.

4. Артьомов М.П. Дослідження динаміки машинно-тракторних агрегатів за допомогою методу парціальних прискорень / М.П. Артьомов // Збірник наукових праць (галузеве машинобудування, будівництво). - 2012. № 2 (32), T. 1. - C. 3-12.

5. Ovsyannikov S. Oscillation process of multi-support machines when driving over irregularities / S.Ovsyannikov, E.Kalinin, I.Kolesnik // Energy Management of Municipal Transportation Facilities and Transport. - Springer, Cham, 2018. - P. 307-317. - doi: 10.1007/978-3-030-19756-8_28.

6. Градуировка датчиков при использовании метода парциальных ускорений / А.С. Полянский, Д.М. Клеи, E.А. Дубинин и др. // Вісник НТУ «ХПІ». Автомобіле- та тракторобудування. - 2012. - № 64 (970). - С. $70-74$.

7. Експериментальне дослідження алгоритму керування режимами роботи транспортного агрегату / М.Л. Шуляк, А.Т. Лебедев, М.П. Артьомов, В.П. Мальцев // Системи управління, навігації та зв'язку. 2017. - № 3. - С. 38-42.

8. Кайдалов Р.О. Експериментальне оцінювання тягово-швидкісних показників спеціальної колісної техніки за допомогою мікропроцесорного комплексу / Р.О. Кайдалов, О.В. Літвінов, С.А. Малишкін, В.М. Кашпур // Честь і Закон. - 2018. - Т. 1. - № 64. - С. 95-105.

9. Бондаренко A.I. Методика експериментального дослідження процесу розгону трактора Fendt 936 Vario при виконанні польових та транспортних робіт / А.І. Бондаренко, А.П. Кожушко, М.О. Мітцель, В.Б. Самородов // Вісник Житомирського державного технологічний університету. - Житомир : ЖДТУ, 2014. - № 2 (69). - C. 48-55.

10. Трактори сільськогосподарські. Методи випробувань (ГОСТ 7057-2001, IDT) : ДСТУ ГОСТ 7057-2003.

11. Техника сельскохозяйственная. Методы эксплуатационно-технологической оценки : ГОСТ 24055-2016. Межгосударственный стандарт. - 01.01.2018. - 27 с.

12. «Сільськогосподарська техніка. Визначення тягових показників тракторів. Метод парціальних прискорень» : СОУ-ІІ УкрНДІПВТ ім. Л.Погорілого 71.2-37-046043090-017:2015. - Введ. 14.01.2014. Дослідницьке : Укр НДІПВТ, 2015. - 10 с.

13. Кожушко А.П. Моделювання пов'язаних коливань колісного трактора та цистерни з рідиною на прямому шляху зі складним рельєфом / А.П. Кожушко, О.Л. Григор'єв // Вісник Національного технічного університету «ХПІ». - Харків : НТУ «ХПІ», 2018. - № 27 (1303). - С. 34-61.

\section{References:}

1. Kozhushko, A.P. (2019), «Analiz konstruktyvnykh osoblyvostei prychipnykh ta napivprychipnykh tsystern u skladi mashynno-traktornoho ahrehatu», Visnyk Natsionalnoho tekhnichnoho universytetu «KhPI», No. 5 (1330), pp. 34 40, doi:10.20998/2413-4295.2019.05.05.

2. Langer, T.H., Ebbesen, M.K. and Kordestani, A. (2015), «Experimental analysis of occupational whole-body vibration exposure of agricultural tractor with large square baler», International Journal of Industrial Ergonomics, No. 47, pp. 79-83, doi: 10/1016/j.ergon.2015.02.009.

3. Sekulić, D., Dedović, V., Rusov, S., Šalinić, S. and Obradović, A. (2013), «Analysis of vibration effects on the comfort of intercity bus users by oscillatory model with ten degrees of freedom», Applied Mathematical Modelling, Vol. 37, No. 18-19, pp. 8629-8644, doi: 10.1016/j.apm.2013.03.060.

4. Artyomov, M.P. (2012), «Doslidzhennia dynamiky mashynno-traktornykh ahrehativ za dopomohoiu metodu partsialnykh pryskoren», Zbirnyk naukovykh prats (haluzeve mashynobuduvannia, budivnytstvo), Vol. 1, No. 2 (32), pp. 3-12.

5. Ovsyannikov, S., Kalinin, E. and Kolesnik, I. (2018), «Oscillation process of multi-support machines when driving over irregularities», Energy Management of Municipal Transportation Facilities and Transport, pp. 307-317, doi: 10.1007/978-3-030-19756-8_28.

6. Polyansky, A.S., Klets, D.M., Dubinin, E.A., Salnikov, R.Yu. and Zadorozhnaya, V.V. (2012), «Graduirovka datchikov pri ispolzovanii metoda partsialnyih uskoreniy», Visnyk Natsionalnoho tekhnichnoho universytetu «KhPI», No. 64 (970), pp. 70-74.

7. Shuliak, M.L., Lebedev, A.T., Artyomov, M.P. and Maltsev, V.P. (2017), «Eksperymentalne doslidzhennia alhorytmu keruvannia rezhymamy roboty transportnoho ahrehatu», Systemy upravlinnia, navihatsii ta zviazku, No. 3, pp. 38-42.

8. Kaydalov, R.O., Litvinov, O.V., Malishkin, S.A. and Kashpur, V.M. (2018), «Eksperymentalne otsiniuvannia tiahovo-shvydkisnykh pokaznykiv spetsialnoi kolisnoi tekhniky za dopomohoiu mikroprotsesornoho kompleksu», Chest $i$ Zakon, Vol. 1, No. 64, pp. 95-105. 
9. Bondarenko, A.I., Kozhushko, A.P., Mitzel, M.O. and Samorodov, V.B. (2014), «Metodyka eksperymentalnoho doslidzhennia protsesu rozghonu traktora Fendt 936 Vario pry vykonanni polovykh ta transportnykh robit», Visnyk Zhytomyrskoho derzhavnoho tehnologichnogo universytetu, No. 2 (69), pp. 48-55.

10. NDIfermmash (2003), DSTU HOST 7057-2003 «Traktory silskohospodarski. Metody vyprobuvan» (HOST 70572001, IDT).

11. Standartinform (2018), HOST 24055-2016 «Tehnika selskohozyaystvennaya. Metodyi ekspluatatsionnotehnologicheskoy otsenki», Mezhgosudarstvennyiy standart, $27 \mathrm{p}$.

12. UkrNDIPVT (2015), SOU-II UkrNDIPVT im. L.Pohoriloho 71.2-37-046043090-017:2015, «Silskohospodarska tekhnika. Vyznachennia tiahovykh pokaznykiv traktoriv. Metod partsialnykh pryskoren», Ukr NDIPVT, Doslidnytske, $10 \mathrm{p}$.

13. Kozhushko, A.P. and Hryhoriev, O.L. (2018), «Modeliuvannia poviazanykh kolyvan kolisnoho traktora ta tsysterny z ridynoiu na priamomu shliakhu zi skladnym reliefom», Visnyk Natsionalnoho tekhnichnoho universytetu "KhPI», No. 27 (1303), pp. 34-61.

Кожушко Андрій Павлович - кандидат технічних наук, доцент кафедри автомобіле- та тракторобудування Національного технічного університету «Харківський політехнічний інститут».

Наукові інтереси:

- динаміка руху колісних тракторів з агрегатами змінної маси.

Колєснік Іван Васильович - кандидат технічних наук, асистент кафедри тракторів та автомобілів Харківського національного технічного університету сільського господарства імені Петра Василенка.

Наукові інтереси:

- експрес-метод контролю технічного стану рульового керування трактора на транспортних роботах.

Лупенко Владислав Віталійович - магістрант, лаборант кафедри тракторів та автомобілів Харківського національного технічного університету сільського господарства імені Петра Василенка.

Наукові інтереси:

- ефективність експлуатації тракторів на транспортних роботах.

Стаття надійшла до редакції 05.09.2019. 